\title{
SYNERGY OF BANKS' AMALGAMATION AND LOANING BY SMALL AGRO-BASED FIRMS: EVIDENCE FROM NIGERIA
}

\author{
Akabom I. Asuquo*, Ashishie Peter Uklala, Mkpa Ubuo Linus and Innocent O. Odey \\ Accounting Department, Faculty of Management Sciences, University of Calabar, \\ P.M.B. 1115, Calabar, Cross River State, Nigeria \\ *Correspondence/Lead Author: University of Calabar, Calabar, Cross River State, Nigeria
}

\begin{abstract}
The synergy of banks' amalgamation and the loaning practices of small agrobased firms were investigated. Facts were drawn together by cross segmental explorative schemes and were evaluated by the regression technique. The evaluation revealed that banks' pre-fused and post-fused bonds were absolutely connected to small agro-based firms loaning. Hence, the studied banks have both fixed and vibrant implications on small agro-based firms loaning. For these reasons, owners and managers of small agro-based firms should take the suggestions of this exploration into consideration when making decisions on loaning facilities from amalgamated banks.
\end{abstract}

Key words: Amalgamation; Agro-based; Bank; Evidence; Firms; Loaning; Small

Cite this Article: Akabom I. Asuquo, Ashishie Peter Uklala, Mkpa Ubuo Linus and Innocent O. Odey, Synergy of Banks' Amalgamation and Loaning by Small AgroBased Firms: Evidence from Nigeria, International Journal of Management, 11(12), 2020, pp 1111-1118.

http://iaeme.com/Home/issue/IJM?Volume=11\&Issue=12

\section{INTRODUCTION}

The contemporary restructurings in financial transactions and funding structure in our country could not have come as astonishment to small business organizations and financial analysts who are observing the wellbeing and the healthiness of financial institutions or the banking sector. The frequency and regularity of distraught in addition to bankruptcy and indebtedness in the funding and financial sector is a common issue. Hence, amalgamation and consolidation has been a solid way out of these problems and also a way of improving the loaning and advancing of the financial institutions or banks to small business organizations, which in our exploration is the small agro-based firms, Iganiga, [1], and Imah, [2].

Exceptional modern restructurings comprise the upsurge in the least funded investment of banks; the rough guide of the worldwide financial transactions; the assumption of the 
exigency scheduling designed for organized catastrophe structure; the advancement of the program and technological development aimed at upright commercial control; the institution of reimbursement bank scheme, which fosters amalgamation and consolidation of banks. The veracity nevertheless, remained that the funding structure happened to be categorized by dint of reduced commercial control in addition to being susceptible to failure; also the economy was bastardized with the inhibited progression of price rises as well as extraordinary charge ratio plus decayed tangible division, Tumkella [3], Zombo [4], Hanahan and Kenggehial [5]

The synergy of amalgamation plus consolidation on bank loaning activities is somewhat multifaceted, which subdivided into fixed impact and vibrant impact. Entrapping the impacts permits one to recognize further the existing collected works on how amalgamation plus consolidation impact on small agro-based firms loaning. The fixed influence is basically the outcome as of the funding of basics amalgamation the pre-amalgamation and consolidation resources into a greater establishment by a joint stability pane besides a viable situation. The fixed influence might be predictable to upshot in a diminished source of small agro-based firms' advances, then the superior investment establishments incline to make a smaller number of small business mortgages per naira of resources, Benston, William, and Larry [6]. The reorganization influence is an energetic influence of the amalgamation plus consolidation as a result of variation concentration caused by organization aberrations in dimensions, economic circumstance, or modest situation initial standards after concluding an amalgamation and consolidation. Therefore, the exploration of amalgamation and consolidation is a worthwhile alternative aimed at improved viability of banks as well as the accessibility of resources designed for loaning to small agro-based firms was prompted to scrutinize the strong point in addition to the advantage of amalgamation in addition to consolidation in making finances for loaning to small agro-based enterprises.

\section{LITERATURE REVIEW}

\subsection{Bank investment prototype and lifespan method for loaning to small agro- based firms}

This prototype reflects on loaning character of the bank to small agro-based to be impacted by a resources admissibility obligation. Obamuyi [7] pointed out bank resources and investment network observe a modification and fluctuation pertaining to interest ratio as upsetting loaning and advancing from the side of banks' resources, predominantly once banks' loaning is inhibited using the appropriateness of a resource condition. The lifespan tactic which is designated and explained by Weston and Brigham [8], existed on the basis of speedy progress in addition to the absence of right of entry to the resources advertises and drive. Compact agro-based corporations are regarded as commencing by means of proprietors' and investors' capitals and assets. Supposing the businesses subsisted, the hazards and vulnerability of less than capital requirement sooner or later surface, at that juncture the manager definitely have to seek alternative means financing the operations of the organization either through business credit facilities besides diminutive-tenure advances offered by banks, speedy and fast progress might result in the difficulty of insolvency and indebtedness. Self-motivated trifling businesses might consequently pick out amid decreasing their advancement by resorting to inside created resources or look out for loaned resources and capital, Weston and Brigham $[8]$.

\subsection{Striking Edict Perception Plus Loaning Provision for Agro-Based Firms}

Striking edict perception states that companies fund the investment activities of the organization in a categorized direction, initially considering the fund within, and then the exterior sources such as loans and venture capital. The culture is generally found amongst 
small businesses, which in this exploration is the small agro-based firms, Myers [9]. Hitches connected with default in payment by small agro-firms might illuminate the larger need of warranty loaning to small firms as a way of doing away with intervention difficulties. Financiers' attitudes for handling the difficulties also, augment considerably to the cost of handling the unpaid loans. Likewise, big business organizations have their creditworthiness assessment is done only based on the valuation of normal business accounts as well as backup records delivered by them on the application for loans, but small firms' evaluation for loaning purposes is always more tedious then the former, thus involving greater business deal charge than normal, Bellow [10], Coase [11], Jensen and Meckling [12], Stiglitz and Weiss [13].

\subsection{Uncertain Components Threatening Fused Banks Loaning to Small Agro- Based Firms}

Hallberg [14], Jombo [15] and Ojo [16] suggested that, the banks' failure to give finances and advances to small business firms is as a result of specific difficulties and complications related to the firms in question, other than insufficient banks' loaning funds, and capital due to resources appropriateness percentage in addition to extra controlling and monitoring necessities. The most important causes of inaccessibility of small businesses to credit facilities or loans may be pointed out as reduced creditworthiness, absence of security, deprived venture bundle, insufficient best ever as well as great vulnerability. The listed difficulties and complications jointly formed bottlenecks to loaning by amalgamated banks to small businesses. Moreover, loaning to small firms are inhibited greatly by monitoring and controlling necessities. The source of advance by banks hang on the dependability of the division in addition to a number of controlling necessities similar to resources appropriateness proportion, reserve requests, liquidness proportion, interest ratio growths plus the loaning guidelines of the banks. The loaning principles and dogmas stimulate volume of currency existing for loaning through the banks, Pandey [17], Nzotta [18], Craig and Hardee [19], Shapiro and Balbirer [20], Shapiro and Balbirer [21].

\subsection{Impact of Amalgamation and Consolidation of Banks on Trifling Agro-Based Firms' Loaning}

Berger, Kashyap, and Scalise [22], Berger, Robert, Hesna and Udell [23] advocated that bigger, structurally multifaceted establishments which are formed as a result of amalgamation and consolidation possibly will not be susceptible to give out loaning and advances to trifling agro-based firms since these firms are largely unacquainted defaulters and have a high-risk profile in financial dealings. Moreover, disparage financial prudence may come up as a result of loaning to trifling firms since their undertakings are greatly leaned to pieces of machinery as well as expertise which are costly to acquire with not too guaranteed productivity. Guidelines plus measures connected to selection besides checking trifling agro-based firms' mortgagors are usually very tedious with heavy cost involvement. Other than business dimensions, the density of activities can equally have an emotional impact on trifling agrobased business loaning.

Cole, Wokens, and Woodbum [24] averred that previous explorations have recognized objective and robust connection amongst financial transactions establishments' magnitude in addition to the stream of trifling commercial credit, by means of big financial establishments dedicating smaller magnitudes of the resources to trifling commercial loaning compared to small establishments. Berger, Kashyap and Scalise [22] pronounced those loaning tendencies remain fixed as well as being strong-minded using the magnitude of the financial institutions. This ignores the essential features of amalgamation plus consolidation as a vibrant and energetic experience that might include meaningful modifications in managerial deeds away 
from the modest motionless combination of the integrated or amalgamated establishments. Berger and Udell [25], Emeni and Okafor [26], Goldberg and White [27] avowed the existence of additional elements outside the establishment's proportions as well as a structural complication, namely variations ineffectiveness and attractiveness or fluctuations in the gradation of proprietorship mechanism, traditionally, trifling agro-based corporate loaning could be confidently or adversely related capital base and the owners' structure of the loaning financial institutions.

Levonian and Soller [28], Peek and Rosengren [29], Strahan and Weston [30] established that trifling lending organizations lean towards capitalizing considerable greater magnitudes of the resources in trifling commercial credits in place of big establishments. Epstein [31], Demsetz and Strahan [32] opined that fixed influence further conveys effect after merging the business circumstance and external mutable of binary lesser organizations. Furthermore, reorganization impact is a vibrant influence or synergy of amalgamation as a result of the adjustment in upgrading the size of establishments, commercial situation, and the viable situation in net worth once effectuating the amalgamation and consolidation. Additionally, the straight impact is the variation in loaning accountable by straight relocating of consideration in the direction of trifling commercial loaning. It should be pointed out that a straight influence of amalgamation besides consolidation is the variance in banks' loaning once amalgamation had been effected and the loaning of similar organizations.

\subsection{Resources Constriction Prototypical}

Obamuyi [7] explained that capitals and assets shrinking ideal defines the character of banks confines and defines them to the amount of loaning and advances offer out to small businesses, in this case the small agro-based businesses as of the restriction of accessible commercial capitals banking. Essentially, banks' survival exposed those to economical besides supervisory body compulsory resources necessities. Arising from practical drives and commitments, banks' supervisory bodies normally require banks to preserve funds on specified the portion of the bank aggregate resources and the easiest method to do is by amalgamation synergy. Nevertheless, banks might turn out to be further prepared to loan throughout definite phases for the reason enhancement in their essential commercial situation. The exploration observed the synergy of amalgamation and consolidation toward guaranteeing loaning and advancing to small agro-based businesses in the face of constraints on capital requirements for every business.

\section{METHODOLOGY}

\subsection{Research Design}

The exploration design embraced for the study was the cross-sectional survey research design. This choice of the cross-sectional research design was because the data were collected at a particular point in time from the sampled banks

\subsection{Population and Sample Size}

The population of the study was the entire commercial banks that undergone amalgamation and consolidation in Nigeria. Out of the population, five amalgamated and consolidated banks which are involved in agricultural enhancement programs were selected.

\subsection{Data Gathering Methods}

The technique adopted in obtaining data for this study relied much on exhaustive archival research, questionnaire administration and financial records examination. Thus, data for this study were obtained from both primary and secondary sources viz: published articles in 
journals, texts, and materials presented in conferences, newspapers, Annual reports, Central Bank of Nigeria, [CBN] statistical bulletin [33] and internet materials and responses on the administered questionnaires.

\subsection{Model Specification}

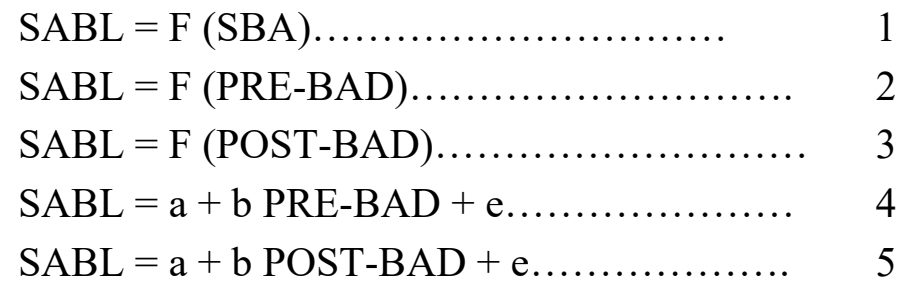

Where SABL = Small agro-based loaning; SBA = Synergy of banks' amalgamation, which is subdivided into pre and post synergies or fixed and vibrant implications respectively; PRE-BAD = pre- bank amalgamation deposit; POST-BAD = post- bank amalgamation deposit, $\mathrm{e}=$ normal slip term

\section{RESULT AND DISCUSSION}

Table 1 Impact of bank amalgamation deposit on small agro-based business advancing using preamalgamated data (fixed synergy).

\begin{tabular}{lccc}
\hline Regressed Variables & Coefficient & T-value & Normal slip \\
Divert & -2258 & -0.96 & 2343.52 \\
Bank deposits & 0.36 & $11.48^{*}$ & 0.03 \\
$R$-square $=0.92$, Adjusted & R-square $=0.92$, F-statistic & $=166.00$, SER $=5975.28 ; D / W=2.27$ \\
* Significant at $5 \%$ level. & & &
\end{tabular}

\section{Source: Authors}

Table 2 Regression results of the impact of bank size, bank financial characteristics, bank advertised shares, amalgamated bank deposit, exterior loan to small agro-based businesses, post amalgamated bank data (vibrant synergy).

\begin{tabular}{|c|c|c|c|c|}
\hline Regressed Variables & Coefficient & & T-value & Normal slip \\
\hline Divert & -2160.27 & -1.54 & & 2174.00 \\
\hline Bank deposits & 0.47 & & $2.91 *$ & 0.1700 \\
\hline Financial features & 3045.20 & & $3.82 *$ & 5463.28 \\
\hline Banks' advertised stocks & -4574.74 & & -0.13 & 1324.87 \\
\hline Post-bank deposit & -1.5000 & & $-4.04 *$ & 0.3600 \\
\hline Pre-bank deposit bank & 2.130 & & $6.34^{*}$ & 0.2800 \\
\hline
\end{tabular}

\section{Source: Authors}

\subsection{Discussion of Findings}

The exploration tried to justify the countless necessity aimed at providing basic facts on the fixed as well as the energetic impact of bank amalgamation on small agro-based firms' loaning in Nigeria. The fixed influence occasioned in an optimistic association amongst small agro-based firms' loaning plus bank dimension since in place of every one currency credit 
conventional approximately $0.36 \mathrm{k}$ is advanced to small agro-based businesses in Nigeria as presented in table 1 above. The outcome of this evaluation is aligned to the submissions made by Cole, Wolkens, and Woodburn [24], Berger, Kashyap, and Scalise [22] and Berger, Robert, Hesna, Scalise, and Udell [23].

Conversely, the vibrant influence of banks' amalgamation on the loaning segment considered in place of rearrangement undeviating as well as peripheral impacts generated contradictory outcomes. Reorganization plus straight impacts demonstrated that bank dimension is adversely correlated to small agro-based business loaning as well as having an adverse connection amongst exterior finance by small financial establishments such as microfunding organizations besides small agro-based business loaning. Inferring from the above results, it implies that the bigger the dimension of the financial institution which is yielded from amalgamation (fixed synergy), the greater the loaning it gives out small agro-based businesses.

Table 2 above which displays regression result showing the impact of bank size, bank financial characteristics, banks' advertised shares, amalgamated, and consolidated-bank deposit on loan to small agro-based businesses (vibrant synergy). The values of bank deposit, financial features, post-amalgamated bank deposit, pre- amalgamated bank deposit which is $2.91,3.82,4.04$ and 6.34 , respectively are significant in the analysis and can be used to predict the dependent variable. The Durbin Watson statistics of 2.27 and 2.12 in both tables 1 $\& 2$ indicate that there is no autocorrelation amongst independent variables.

\section{CONCLUSION}

The exploration evaluated the impact/synergy of banks' amalgamation on small agro-based business loaning by means of facts from financial institutions in Nigeria of the modern periods. The discoveries of the exploration epitomize the general condition about the underlying variables and concepts of the research and could be applicable to other business environments especially when making the decision on an amalgamation as a means of guaranteeing small business loaning. The combined effect/synergy of bank ensures that adequate fund is available for the combined banks to give out loans to Small agro-based firms. The synergy was clearly recognized in the exploration and subdivided into fixed synergy/implication which was ascertained from pre- bank amalgamated data and vibrant synergy/implication which was determined using post- bank amalgamated pieces of evidence.

\section{ACKNOWLEDGEMENT}

The authors greatly appreciate all those who in one way or the other have contributed towards the successful completion of this research work. Thank you very much and God bless.

\section{REFERENCES}

[1] T. H. Iganiga, Future U.S. banking structure: 1990 to 2010, Antitrust Bulletin, 37 (1), 2000) 137-198.

[2] O. I. Imah, Consolidation in the Nigerian banking industry: A strategy for survival and development. A paper presented during the visit of the Nigerian economics students association (NESA), University of Abuja, 2005.

[3] K. Tumkella, The challenge of globalization and SME sector in Nigeria: Repositioning through technology and innovation, paper presented at the national summit on SMIEIS organized by the Bankers' Committee and Lagos Chambers of Commerce and Industry (LCC), Lagos $10^{\text {th }}$ June, 2003. 
[4] B. S. Zombo, Performance evaluation of small-medium enterprises (SMEs) in Nigeria. Central Bank of Nigeria Bullion, 21(4), Oct./Dec., 2005, 46-52.

[5] G. Hanahan, and S. Kenggehial, Mergers and acquisitions in the U.S. banking industry: Evidence from the capital markets, Amsterdam, North Holland, 2001.

[6] G. J. Benston, C. H. William, and D. W. Larry, Motivations for Bank Mergers and Acquisitions: Enhancing the Deposit Insurance put option versus Earnings Diversification, Journal of Money, Credit and Banking 27(1), 1995, 777-788.

[7] E. Obamuyi, Effects of the recapitalization on the Nigerian economy, Sun News Jan., 21, 2007.

[8] D. G. Weston, and K. O. Brigham, Managerial finance (Hindgale: Dryder Press, 1981).

[9] H. D. Myers, Policy Implications of purely strategic mergers, Elsner \& Groenewegen, eds. 1984.

[10] G. J. Bellow, De Novo Banks and lending to small businesses: An exploratory analysis, working paper, New York University, Feb., 2005, 1-15.

[11] R. H. Coase, The nature of the firm, Economica, 4 (1), 1937, 386-405.

[12] B. N. Jensen, and A. C. Meckling, Entry restrictions, industry evolution and dynamic efficiency: Evidence from commercial banking, "Federal reserve banking of New York, working paper, August, 1976.

[13] P. E. Stiglitz, and J. O. Weiss, Small business lending and the changing structure of the banking industry, working paper, Federal Reserve Bank of New York, Jan., 1981.

[14] K. A. Hallberg, Market-oriented strategy for small and medium scale enterprises.' International Finance Corporation, Discussion paper 40, April, 2000.

[15] G. E. Jombo, A review of small-scale enterprises credit delivery strategies in Nigeria.

[16] Central Bank of Nigeria's Economic and Financial Review, 30 (4), 2005) 249-278.

[17] A. T. Ojo, Partnership and strategic alliance for effective SME development, small and medium enterprises development: Effective implementation strategies (Lagos: CIBN Press Ltd., 2003).

[18] J. F. Pandey, Banking relationships, financial constraints and investment: Area bank dependent borrowers more financially constrained, University of Florida working Paper, Dec., 2005.

[19] J. A. Nzotta, Partnership and strategic alliance for effective SME development, small and medium enterprises development: Effective implementation strategies (Lagos: CIBN Press Ltd., 2002).

[20] S. G. Craig, and P. Hardee, The impact of bank consolidation on small business credit availability. Central Bank Statistical publication, 2004.

[21] M. H. Shapiro, and R. Balbirer, Bank capital and the credit crunch: The roles of risk-weighted and unweight capital regulations AEEUEA, 22(1), Jan., 2002, 59-94.

[22] M. H. Shapiro, and R. Balbirer, Bank Commercial loan markets and the role of market structure: Evidence from surveys of commercial lending. Journal of Banking and Finance, 15 (1), Feb., 2008, 133-149.

[23] A. N. Berger, A. K. Kashyap, and J. M. Scalise, The transformation of the U.S. banking Industry: what a long strange trip, It's been brookings papers on economic activity U.S., 1995.

[24] A. N. Berger, D. Robert, G. Hesna, and G. F. Udell, The globalization of financial institution: evidence from cross-border banking performance. Brookings-Wharton paper on Financial Services. Journal of Banking and Finance. 2(22), 2000, 851-867. 
[25] R. A. Cole, J. D. Wokens, and L. R. Woodbum, Banking and nonbank competition for small business credit: Evidence from the 1987 and 1993 national survey of small Business finances. Federal Reserve Bulletin, 82 (11), 1996, 95-983.

[26] A. N. Berger, and G. F. Udell, Universal banking and the future of small business leading edited by Saunders and Ingo Walter," Financial Systems Design: The case for universal banking, Inwin, Burr Ridge, IL, 1996.

[27] G. A. Emeni, and T. R. Okafor, Selected essays on contemporary issues in the Nigerian Banking System, (Ibadan: Ibadan University Press, 2005).

[28] L. G. Goldberg, and L. G. White, De novo Banks and leading to small business, De novo banks training workshop paper, 1998.

[29] M. Levonian, and J. Soller, Small banks, small loans, small business, Federal reserve bank of San Francisco working paper of Missouri, Sept., 1995.

[30] J. Peek, and E. S. Rosengren, Small business credit availability: How important is size of lender? Edited by Anthony for universal banking, Irwin, Burr Ridge IL, 1996.

[31] P. E. Strahan, and J. Weston, Small business lending and bank consolidation: Is there cause for current issues in economics and finance 2, Federal Reserve Bank of New York, 1996.

[32] S. P. Epstein, The impact of mergers on bank operating performance, working paper, Tulane University, 1993.

[33] R. Demsetz, and R. Strahan, Diversification, size and risk at bank holding companies. Journal of Money Credit and banking, 29 (1), 1997, 300-313.

[34] Central Bank of Nigeria [CBN]. Guidelines and incentives on consolidation in the Nigeria Banking industry, Press releases (April 11, 2005) on banking sector consolidation: special incentive to encourage weaker banks, 2005. 